\title{
Econometrics analysis of soybean production in Doma Local Government Area of Nasarawa State, Nigeria
}

\author{
Girei, A. A. ${ }^{{ }^{*}}$, Ohen, S. B. ${ }^{2}$ and Filli, F. B. ${ }^{3}$ \\ ${ }^{1}$ Department of Agricultural Economics and Extension, Nasarawa State University, Keffi, Nigeria. \\ ${ }^{2}$ Department of Agricultural Economics, University of Calabar, Calabar, Cross River State, Nigeria. \\ ${ }^{3}$ Department of Agricultural Economics and Extension, Federal University, Wukari, Taraba State, Nigeria. \\ ${ }^{*}$ Corresponding author. Email: agirejo@gmail.com
}

Copyright ( 2018 Girei et al. This article remains permanently open access under the terms of the Creative Commons Attribution License 4.0, which permits unrestricted use, distribution, and reproduction in any medium, provided the original work is properly cited.

Received 23rd March, 2019; Accepted 7th May, 2019

\begin{abstract}
The study is on economic analysis of soybean production in Doma Local Government Area of Nasarawa State, Nigeria. The objectives of the study were to describe the socio-economic characteristics of soybeans farmers and estimate the production function for soybeans in the study area, estimate the cost and return of soybeans production. A simple random sampling technique was used to select 120 respondents. Primary data were collected with a structured questionnaire. The data were analyzed using descriptive statistics; mean percentage and frequency and production function. The result showed that the soybeans farmers were mostly young people, married, and literate with large household sizes. Also, $88.3 \%$ of the farmers cultivated less than one hectare, while $11 \%$ cultivated between 1.0 to 2.0 hectares of land. The estimated production function had a coefficient of determination $\left(R^{2}\right)$ of 0.943 , implying that about $94.3 \%$ variation in the output of soybeans were accounted for by seed and labour, that increase in any of the variables will lead to increase in output of soybeans. The study, therefore, recommended that improved inputs be made available on time, in right amounts and at affordable prices to the farmers by the government and other stakeholders in other to enhance production.
\end{abstract}

Keywords: Analysis, production function, soybean.

\section{INTRODUCTION}

Nigeria with an estimated population of $161,004,058$ people (Indexmundi, 2012) is Africa's most populous country and agriculture is the center of activity of her people. Although, the economy now relies heavily on the petroleum sector (which generates three-quarters of government revenues and more than $90 \%$ of foreign exchange earnings), agriculture continues to play an important role in the economy (Ugwu, 2009). The author added that the sector currently contributes $26 \%$ to the Gross Domestic Product (GDP), with crop production accounting for an estimated $85 \%$ of this total, livestock contributing $10 \%$ with the remainder made up by forestry and fisheries. According to the Federal Ministry of Agriculture and Rural Development (FMARD, 2006), the agricultural sector generates about $90 \%$ of the non-oil export revenues, employs about one-third of the total labor force and provides a livelihood for the bulk of the rural population.

One of the major food problems in Nigeria is the gross deficiency in protein intake, both in quantity and quality (Dashiell, 1998). Although protein in the human diet is derived from both plant and animal sources, the declining consumption of animal protein due to its high prices requires alternative sources. Soya bean provides a cheaper and high protein rich alternative substitute to animal protein. It is an important crop in the world and has been the dominant oilseed since the 1960s (Smith and Huyser, 1987). It is a multipurpose crop and its importance ranges from its use in milk production, oil processing, livestock feeds, medical, industrial and human consumption and more recently, as a source of bio-energy (Adedoyin et al., 1998; Myaka et al., 2005). 
Soya bean, belong to family leguminosae, subfamily papiplonaceae, and the genus Glycine max (L) Merril, has been receiving attention as a source of food capable of increasing the available protein supplies. Consequently, interest in the production, processing and utilization of the crop has been growing (Osho, 1991). Soybean grows in tropical, subtropical, and temperate climates. It was domesticated in the 11th century BC around northeast of China. It is believed that it might have been introduced to Africa in the 19th century by Chinese traders along the eastern coast of Africa (Shurtleff and Aoyagi, 2007). The plant, according to Ryan et al. (1986), is grown in rather small holder farms in most African countries including Nigeria. Ashaye et al., (2005) identified the Guinea savannah zone of Nigeria as the main area of production ranking Benue State first among the specific areas in the Zone. Dashiell (1992) reported that Benue State cultivates about $70 \%$ of the national total annual soya grain production. The remaining $30 \%$ is gotten from Nasarawa, Kaduna, Kwara and the Niger States and parts of the Federal Capital Territory (FCT) (FMINO, 2002). Ezedinma (1965), who reviewed the history of the crop in Nigeria, reported that soybeans were first introduced in 1908 by the British looking for new sources of supply from their colonies.

Undoubtedly, Soya bean is one of nature's most efficient protein producers. According to Ryan et al. (1986), it yields more protein per acre than any other commonly cultivated crop, at least three times more than rice, wheat or maize. Sachel and Litchfield (1965) measured about 40 percent high quality protein in Soya bean and that while most plant protein sources are seriously deficient in one or more of nine essential amino acids, Soya bean is an exception. According to them, Soya bean is an excellent source of unsaturated oil with most varieties averaging a content of about 20 percent.

Onochie (1965) discussed the potential value of Soya bean as a protein supplement in Nigerian diet. He observed that Soya bean has a higher total digestible nutrient percentage of (91. 99\%) than cowpea $(79.52 \%)$ and therefore more metabolizable energy and a higher content of lysine (6.0 to $6.5 \%$ ) than all other common vegetable protein sources. Soya bean nutritional values account for the various ways it is used in human diets today; it is used as a soup condiment especially for thickening purposes.

There is Soyamilk, Soyadrink, Soyagari, Soyaeba and Nune or "Dawadawa". The chaff obtained after threshing can be fed to animals and the cake after extracting oil is widely used in the production of livestock feed. Soya bean is also very important in the treatment of some sicknesses. Naganawa et al. (1988) observed that it would be helpful to give a diet with Soya bean protein to patients with Cirrhosis to prevent protein malnutrition. Also, Chandrasekhar and Paul (1989) reported that supplementation of Cancer patients' diets with Soya flour for 3 months improved their nutritional profile. Another study by Lee (1991) showed that Soya bean products may be a protection against breast cancer in younger women since these foods are rich in phyto-estrogens.

Soya bean has a lot of high quality protein, Uwaegbute (1992) reported that Soya bean is one of the cheapest foods available to man when judged by the amount of protein, mineral, vitamins and energy obtainable per unit cost, and its high protein content makes it a very useful food for curing protein energy malnutrition. The grain legume proteins are usually the least expensive source for both rural and urban population, and nutritionally, the protein of Soya bean is similar to that of animal protein. The amino acid analysis of Soya bean protein and Casein are remarkably similar (Masefield, 1977). Norman (1978) reported that the thought for utilization of Soya bean protein products in human foods has increased dramatically because of the population pressure on the food supply and the quest for the alternative source of protein. This is more so in developing countries where there is a great shortage of animal protein leading to a lot of nutritional hazards. A great effort has to be made to enrich some foods with Soya bean.

Soya bean is an important crop produced mainly in the Guinea Savannah zone of Nigeria. However, it was reported that the crop is grown in rather small holder farms in most African countries including Nigeria (Olorunsanya et al., 2009). Available statistics on world soya bean production shows that although production tends to increase between the year 2000 and 2006, there is a marked decline in the production of soya bean in the year 2007. Also, the contribution of Nigeria to world soya bean production which stood at an average of $0.28 \%$ in 2006 , declined to about $0.26 \%$ in 2007 (FAOSTATS, 2009). Research has shown that the problems of small scale agriculture in Nigeria include the lack of high yielding cultivars, inadequate information about new production technology, inadequate basic farm inputs and the use of traditional techniques with low productivity.

The production process involves the transformation of inputs into outputs. What is put into production process comes out either as a product or in the form of waste. The product is that part of the output that is valuable to the producer while that which has no value to him is the waste or waste product. Every production process therefore generates some waste products. As long as the production generates sufficient profit from the valuable part of the output, the investor is satisfied with the investment (Olukosi and Ogungbile, 1989). In agriculture, inputs are usually classified as land, labor, capital, and management. These are usually coordinated by the producing unit whose ultimate objectives or goals may be profit maximization, output maximization, cost minimization, the maximization of satisfaction, or a combination of these motives (Olayide and Heady, 1982).

In a production process, a relationship exists between the quantity of output produced and the quantities of inputs used. In other words, variability in the quantity of output is 
determined by the variability in the quantities of inputs used. The production function describes the technical or physical relationship existing between inputs and outputs in any production process. In mathematical terms, this function is assumed to be continuous and differentiable thus, enabling us to estimate the rates of returns (Olayide and Heady, 1982). The production function takes many forms and has become one of the most widely used tools in economic analysis. The choice of any form will depend on its desirable characteristics. Griffins et al. (1987), suggested choice of functional form based on statistical and econometric criteria. They added that, the goodness of fit $\left(R^{2}\right)$, is a statistical significance of the regression coefficients and the correctness of the signs of the regression coefficients.

On the basis of this discussion, this article was based on econometrics analysis of soybean production in Doma Local Government Area of Nasarawa State, Nigeria with specific objectives of identifying the socioeconomic characteristics of soybeans farmer in the study area and determine the factors affecting soybeans production in the study area.

\section{METHODOLOGY}

\section{The study area}

The study was conducted in Doma Local Government Area (LGA) of Nasarawa State. It is one of the thirteen (13) LGA's of the State and located in the Southern Zone of the Nasarawa Agricultural Development Programme (NADP). Doma is been the LGA headquarter and about $22 \mathrm{~km}$ West of the State capital, Lafia. It lies between latitude 7 and $9^{0}$ 33' $\mathrm{N}$ and longitude 7 and $10^{\circ} 32^{\prime} \mathrm{E}$. Doma has distinct wet (March to October) and dry (November to February) seasons. The average rainfall of the study area is approximately $107.6 \mathrm{~mm}$ and has high temperature throughout the year with an annual mean ranging between 22.7 and $36.8^{\circ} \mathrm{C}$. The soil texture is sandy loam which supports the production of varieties of crops such as cassava, yam, beniseed, melon, rice, millet, maize, groundnuts, and sorghum among others. The LGA covers a land area of $2,714 \mathrm{~km}^{2}$ and has estimated population of 184,009 inhabitants applying 2.8 percent annual growth rate (NPC, 2006). Main tribes that live in the area are; Alago, Agatu, Migili, Eggon, Bassa, Tiv, Hausa/Fulani, and Mada. The LGA shares border with Lafia, Keana, Keffi and Kokona to the East, East-South, South-West and West respectively. The major occupation of the inhabitants is farming.

\section{Sampling technique and sample size}

Multistage sampling technique was adopted in the selection of the respondents for the study as follows: stage
1; three districts were randomly selected from Doma Local Government. Stage 2; four villages were selected purposively because of intensive farming nature of the villages making a total of 12 villages. Stage 3; random sampling was used to get the farmers proportionately to the population of each village. Lastly, 120 questionnaires were drawn from the respondents and formed the sample size of the study.

\section{Data collection}

Primary data were collected with the aid of a structured questionnaire. Information collected from the respondents was on their socioeconomic characteristics such as age, education level, sex, marital status. Information was also collected on inputs used in soybean production. The Price of inputs such as soybean seed, labour, fertilizer and insecticides was obtained.

\section{Analytical technique}

Descriptive statistics (mean, frequency distribution and percentage) and multiple regression analysis were used to achieve the objectives of this study. The multiple production function was specified in four functional forms (linear, exponential, semi-log and double log) in order to select the model with the best fit. The general form of the production function is:

$Y=f\left(X_{1}, X_{2}, X_{3}, X_{4}, X_{5}, X_{6} \ldots \ldots \ldots . . . .\right.$.

Linear function

$Y=b_{0}+b_{1} X_{1}+b_{2} X_{2}+b_{3} X_{3}+b_{4} X_{4}+b_{5} X_{5}+b_{6} X_{6}+e$

Exponential function

$\log Y=b_{0}+b_{1} X_{1}+b_{2} X_{2}+b_{3} X_{3}+b_{4} X_{4}+b_{5} X_{5}+b_{6} X_{6}+e$

Semi Log Function

$Y=b_{0}+b_{1} \log X_{1}+b_{2} \log X_{2}+b_{3} \log X_{3}+b_{4} \log X_{4}+$ $b_{5} \log X_{5}+b_{6} \log X_{6}+e$

Double Log Function

$\log Y=b_{0}+b_{1} \log X_{1}+b_{2} \log X_{2}+b_{3} \log X_{3}+b_{4} \log X_{4}+$ $b_{5} \log X_{5}+b_{6} \log X_{6}+e$

Where: $Y=$ Quantity of soybeans produced in land area $(\mathrm{Kg}), X_{1}=$ Quantity of seeds $(\mathrm{Kg}), X_{2}=$ Quantity of fertilizers $(\mathrm{Kg}), X_{3}=$ Quantity of herbicides $(\mathrm{Ltr}), \mathrm{X}_{4}=$ Depreciation on Implement $(\mathrm{Y}), \mathrm{X}_{5}=$ Labour (Man/Day), $\mathrm{X}_{6}=$ Transportation $(\mathrm{N})$ and $\mathrm{e}=$ error term. 


\section{RESULTS AND DISCUSSION}

\section{Socio-economic characteristics of the respondents}

\section{Distribution of respondents according to age}

Table 1 reveals age distribution between 20 to 29 years are $31.7 \%$, 30 to 39 years $26.7 \%$, 40 to 49 years $20.8 \%$, 50 to 59 years $16.7 \%$, and 60 years above is $4.2 \%$. This means that the respondents were still in their active age. Age has a significant influence on the decision making process of farmers with respect to risk aversion, adoption of improved agricultural technologies, and other production related decisions. According to Omolehin et al. (2011) and Girei et al. (2016), young people tend to withstand stress, put more time in agricultural operations which can lead to increased output and consequently higher income and improved social and economic wellbeing of the farmers.

\section{Distribution of respondents according to sex}

The result on the sex distribution of respondent as presented in Table 1 shows that majority of respondents were male $62.5 \%$ while $37.5 \%$ were female. This implies that the male dominated soybean production and this may be due to the fact that the female may have been engaged in other domestic household activities and other related farm services. The results of this study is similar to the findings of Biam et al. (2016) who opined that majority of the soybean farmers in the study zone were male.

\section{Distribution of respondents according to marital status}

The result shows that majority of the soybean farmers in the study area were married $60.0 \%, 24.2 \%$ were single, $6.7 \%$ were a widow, $5.0 \%$ widower, and $4.2 \%$ divorced (Table 1). This indicates that, most of the married farmers were tasked with family burden which makes them to be involved in such activity for additional to carter for the basic family need.

\section{Distribution of respondents according to household size}

On the household size, the analysis shows that only $30.0 \%$ had household size ranged between 1 and 5 persons indicating that the farmers in the study area had low household size. The majority of soybean farmers (63.3\%) were having 6 to 10 members in their household, while $6.7 \%$ were having more than 10 members in their household (Table 1). This showed that majority $70 \%$ of the farmers were having large household size and need extra income for their larger household need.
Table 1. Socioeconomic characteristics of the respondents.

\begin{tabular}{|c|c|c|}
\hline Variable & Frequency & Percentage \\
\hline \multicolumn{3}{|l|}{ Age (years) } \\
\hline$<29$ & 38 & 31.7 \\
\hline $30-39$ & 32 & 26.7 \\
\hline $40-49$ & 25 & 20.8 \\
\hline $50-59$ & 20 & 16.7 \\
\hline$>60$ & 5 & 4.2 \\
\hline Total & 120 & 100 \\
\hline \multicolumn{3}{|l|}{ Sex } \\
\hline Male & 75 & 62.5 \\
\hline Female & 45 & 37.5 \\
\hline Total & 120 & 100 \\
\hline \multicolumn{3}{|l|}{ Marital Status } \\
\hline Single & 29 & 24.2 \\
\hline Married & 72 & 60.0 \\
\hline Widowed & 14 & 11.7 \\
\hline Divorce & 5 & 4.2 \\
\hline Total & 120 & 100 \\
\hline \multicolumn{3}{|l|}{ Household size } \\
\hline$<5$ & 36 & 30.0 \\
\hline $6-10$ & 76 & 63.3 \\
\hline$>10$ & 8 & 6.7 \\
\hline Total & 120 & 100 \\
\hline \multicolumn{3}{|l|}{ Educational Status } \\
\hline Non-formal Education & 34 & 28.3 \\
\hline Primary & 21 & 17.5 \\
\hline Secondary & 47 & 39.2 \\
\hline Tertiary & 18 & 15.0 \\
\hline Total & 120 & 100 \\
\hline \multicolumn{3}{|l|}{ Farming Experience } \\
\hline $1-10$ & 61 & 50.8 \\
\hline $11-20$ & 42 & 35.0 \\
\hline $21-30$ & 17 & 14.2 \\
\hline Total & 120 & 100 \\
\hline \multicolumn{3}{|l|}{ Farm Size } \\
\hline$>1$ ha & 14 & 11.7 \\
\hline$<$ ha & 106 & 88.3 \\
\hline Total & 120 & 100 \\
\hline \multicolumn{3}{|l|}{ Extension Contacts } \\
\hline No visit & 74 & 61.7 \\
\hline Once & 9 & 7.5 \\
\hline Twice & 30 & 25.0 \\
\hline More than Twice & 7 & 5.9 \\
\hline Total & 120 & 100 \\
\hline
\end{tabular}


Table 1. Contd.

\begin{tabular}{lcc}
\hline Variable & Frequency & Percentage \\
\hline Mode of Land acquisition & & \\
Inheritance & 61 & 50.0 \\
Lease & 23 & 19.2 \\
Gift & 23 & 19.2 \\
Share cropping & 13 & 10.8 \\
Total & 120 & 100 \\
\hline
\end{tabular}

Source: Field survey, 2016.

\section{Educational level of the respondents}

The findings of the study have shown that $28.3 \%$ of the respondents never attended formal school while $17.5 \%$ had primary education. On the other hand, respondents who had secondary and tertiary education constituted $39.2 \%$ and $15.0 \%$ respectively (Table 1 ). This implies that majority of the respondents had a formal education, meaning that they are literate. Adoption of innovations can be influenced by education (Ahmadu, 2011). This implies that, education has to play important role in the different aspect of agricultural development in the study area as well as the nation at large. Ojuekaiye (2001) reported that education is an essential socio-economic factor that influences farmer's decision because of its effect on the awareness, perception, reception and quick adoption of innovation that can increase productivity and efficiency of enterprise development and management. The study is also in line with the result obtained by Biam et al. (2016) who reported in a similar study conducted in Makurdi, Benue State, Nigeria that majority of the soybean farmers in the area had a moderate level of education.

\section{Farming experience of the respondents}

Table 1 also revealed that $50.8 \%$ of the respondents had less than 10 years' experience in soybean production, $35.0 \%$ had 11 to 20 years, while $14.2 \%$ had 21 to 30 years of experience. This implies that the majorities were quite experienced in soybean production indicating that there is profit in soya beans farming in the study area. This result is in support of the findings of Biam et al. (2016).

\section{Farm size of the respondent}

Size of farm cultivated is a function of population pressure, family size and financial back ground of the farmers (Ahmadu, 2011). One of the major characteristics of smallscale farming is fragmented land holding. As presented in Table1, the result of this study shows that $88.3 \%$ of the respondents cultivated on less than one hectare, while only $11.7 \%$ of them cultivated 1.0 hectare or more. This implies that most of the Doma soybean farmers were small-scale farmers. Small farm size is an impediment to agricultural mechanization because it will be difficult to use farm machines on small and fragmented farms. This also conforms to the study of Ekong (2003) who opined that most Nigerian farmers are small sized family farms in which family members contribute the required labour. This further corroborated the findings of Biam et al. (2016) that majority of the soybean farmers in their area were male with moderate education and highly experienced in soybean farming with small land holdings.

\section{Extension contacts}

Majority of the respondents (61.7\%) had no any extension visit, $7.5,25.0$, and $4.2 \%$ of the respondents were visited once, twice, and more than twice times respectively (Table 1). With the importance of extension services to farmers, this shows that majority farmers need additional visit.

\section{Mode of land acquisition}

The mode of land acquisition of respondents in the study area is presented in Table 1. About $50.8 \%$ of the respondents acquire the farm land through inheritance, $19.2 \%$ through lease, $19.2 \%$ through gift and 10.8\% through share cropping. Land is a very important factor of production showing that farmers should not depend on the conventional inheritance and increase their sources of land for farming for maximum output.

\section{Production function for soybean in the study area}

The production function for this study was estimated using four functional forms. The double log form was selected to serve as the lead equation and thus was further explained. The adjusted of $R^{2}$ was 0.943 which implied that about 94 percent of soybeans output variation was accounted for by the independent variables included in the model and the estimated F-ratio was 327.65 and significant at 1 percent level of probability meaning that the model was significant entirely and best fit for this analysis (Table 2).

The coefficient of all the variables was positive implying that increasing in any of the variables will lead to increase in output of soybeans.

Specifically, the seed was positive and significant at $1 \%$ with a coefficient of 0.381 , this indicates that 0.381 increase in a kilogram of seeds will increase the output by one kilogram. Production tools and implements were positive and significant at $1 \%$ with coefficient of 0.124 ; this showed that $0.124 \%$ increase in utilization of inputs will lead to one percent (1\%) increase in output. Labour employed by farmers was positive and significant at $1 \%$ with a coefficient of 0.590 ; this suggested that $0.590 \%$ increase in the labor force will add output by $1 \%$. The coefficient of fertilizers and herbicides though positive, 
Table 2. Estimates production function on the influence of inputs on the output of soybeans.

\begin{tabular}{lccc}
\hline Constant input & Coefficient & Standard error & t - ratio \\
\hline Constant & 0.761 & 0.426 & $1.786^{*}$ \\
Seeds & 0.381 & 0.074 & $5.127^{*+*}$ \\
Fertilizers & 0.001 & 0.002 & $0.50^{\mathrm{NS}}$ \\
Herbicides & 0.002 & 0.002 & $1.00^{\mathrm{NS}}$ \\
Implement & 0.124 & 0.029 & $4.28^{* *+}$ \\
Labour & 0.590 & 0.081 & $7.28^{* * *}$ \\
$\mathrm{R}^{2}=0.972$ & & & \\
Adjusted $\mathrm{R}^{2}=0.943$ & & & \\
F-ratio $=327.648$ & & & \\
\hline
\end{tabular}

Source: Field survey, 2016. *Significant at $10 \%$ level and ${ }^{* \star \star}$ Significant at $1 \%$ level.

were not significant determinant of soybeans production at the conventional level (Table 2). This may be due to the fact that farmers did not make much use of these inputs.

\section{Conclusion and recommendations}

The results of this study showed that the soybeans farmers were mostly young people, married, and literate with large household size. In addition, the respondents operated on inheritance farm lands. The coefficient of determination $\left(R^{2}\right)$ was estimated at 0.943 , implying that about $94.3 \%$ variation in the output of soybeans was accounted for by the variables included in the model while the F-ratio was found to be 327.648 and significant at $1 \%$. The coefficients of seeds, implement and labor was positive and significant at one percent, while fertilizer and herbicides were not significant at the conventional level. From the results obtained from this study, the following recommendations were made;

1. The farmers should increase and improve inputs such as seeds, implement and labour as this are inputs that affects outputs positively.

2. Farmers should be provided with adequate extension services that will help in building their capacities and competencies towards re-addressing agriculture from what it is (occupation) to what it ought to be (business enterprising) and.

3. Farmer should diverse their sources of land, not to depend on inheritance with fragmentation by nature.

\section{CONFLICT OF INTEREST}

The authors declare that they have no conflict of interest.

\section{REFERENCES}

Adedoyin, S. F., Torimiro, D. D., Joda, A. O., \& Ogunkoya, A. O. (1998). Adoption of Soybeans Planting, Processing and
Utilisation Packages in Ago Iwoye, Proceeding of the 3rd Annual National Conference of the Agricultural Extension Society of Nigeria, 4-6 March.

Ahmadu, G. O. E. (2011) Socio-economic factors influencing the level of Rural Youth Involvement in Cassava Production activities in Benue State. An M.Sc Thesis Suibmitted to the Department of Agricultural Economics and Rural Sociology, Faculty of Agriculture, Ahmadu Bello University, Zaria, Kaduna State, Nigeria.

Ashaye, O. A., Adegbulugbe, T. A., \& Sanni, S. (2005). Assessment of Soybean Processing Technologies in Ilorin East and West Local Government Area of Kwara State. World Journal of Agricultural Science, 1(1), 59-61.

Biam, C. K., Okorie, A., \& Nwibo, S. U. (2016). Economic Efficiency of Small Scale Soybean Farmers in Central Agricultural Zone of Nigeria: A Case of Cobb-Douglas Stochastic Frontier Cost Function Approach. Journal of Development and Agricultural Economics, 8(3), 52-58.

Chandrasekhar, U., \& Paul, H. (1989). Nutrition and Life Style of People: Supplementation Studies on Selected Cancer Patients. Indian Journal of Nutrition and Dietetics, 26(8), 219228.

Dashiell, K. (1998). An Effort to Promote the Production and Consumption of Soybean as a Means of Improving Nutrition in Nigeria. IITA, Ibadan, Nigeria.

Dashiell, K. E. (1992). Soyabean Help Farmers, Urban Dwellers and Industries in Nigeria. A paper presented at the 5th Annual Conference of the Nigerian Soyabean Association in Makurdi, Benue State.

Ekong, E. E. (2003). An Introduction to Rural Sociology. Dove educational Publishers, Uyo, Nigeria.

Federal Ministry of Agriculture and National Orientation (FMINO) (2002).

Federal Ministry of Agriculture and Rural Development (FMARD), (2006). National Programme for Food Security (NPFS) Expansion Phase Project 2006-2010. (Main Report).

Food and Agricultural Organization (FAO) (1992). FAO Production Year Book Vol. 45, Rome.

Girei, A. A, Abdullahi, A., \& Ismaila, G. (2016). Determinants of Poverty Coping Strategies among Women Farmers in Yola South Local Government Area of Adamawa State, Nigeria. Asian Research Journal of Agriculture, 2(4), 1-9

Griffins, C. R., Mongomery, M. J., \& Rister, W. E. (1987). Selecting Functional Forms in Production Analysis. Western Journal of Agricultural Economics, 12(2), 216-217.

Indexmundi (2012). Nigeria Population growth rate. Available at 
http://www.indexmundi.com/nigeria/population_growth_rate.html.

Lee, H. P. (1991). Dietary Effect on Breast Cancer, Risk in Singapore Lancet. (British edition). Department of Community, Occupational and Family Medicine. National University of Singapore, Lower Kent Ridge Road, Singapore, 337(8751).

Masefield, G. B. (1977). The Oxford Books of Plants. Oxford University Press.

Myaka, F. A., Kirenga, G., \& Malema, B. (Eds) (2005). Proceedings of the First National Soybean Stakeholders Workshop, 10 - 11 November 2005, Morogoro, Tanzania.

Naganawa, S. (1988). Effect of Soya Protein Diet on Patients with liver cirrohis. Nutritional Science of Soy Protein, Japan. First Dept of International Medicine. Gifu University, School of Medicine, Gifu 503 Japan, 9(1), 101-103.

Norman, A. G. (1978). Soya bean Physiology, Agronomy and Utilization. Academic Press, New York, San Francisco, London.

NPC (2006). National Population Commission Federal Republic of Nigeria Official Gazette 2007: 24 (94).

Ojuekaiye, E. O. (2001). Economic Analysis of Cassava Production in Three Local Areas of the Western States of Nigeria. The Nigerian Journal of Agricultural Economics. 12, 27-35.

Olayide, S. O., \& Heady, E. O. (1982). Introduction to Agricultural Production Economics. University of Ibadan Press, Ibadan, Nigeria.

Olorunsanya, E. O., Babatunde, R. O., Orebiyi, J. S. \& Omotosho, J. O. (2009). Economic Analysis of Soyabean Production in Kwara State, North Central Nigeria. Global Approaches to Extension Practice (GAEP), 5(2).

Olukosi, J. O., \& Ogungbile, A. O. (1989). Introduction to Production Economics: Principles and Application. Agitab Publisher Limited, Zaria, Nigeria, pp. 20-30.

Omolehin, R. A., Adeola. S. S., Ahmed, B., Ebukiba, E. O., \& Adetunji, O. B. (2011). Economics of Insecticide Usage among Cowpea Farmers in Kaduna State, Nigeria. American Journal of Experimental Agriculture, 1(4), 353-362.
Onochie, B. E. (1965). The Potential Value of Soyabean as a Protein Supplement in Nigerian Diet II. Cereal Science Today, 10, 438-461.

Osho, S. M. (1991). Soya Processing and Utilization Research: Why Rapid Rural Appraisal. Soyabean Utilization in Nigeria and Ghana, IDRC/IITA Soyabean Utilization Project Phase 11, 1st Year Technical Report.

Ryan, S. A., Wynstra, R. J., Kauffman, H. E., Jackobs, J. A., \& Gleason, J. E. (1986). The Soyabean Solution, Meeting World Food Needs. Urbana-Champaign, College of Agriculture, University of Illinois. p. 13.

Sachel, G. F., \& Litchfield, L. A. (1965). Technology and Protein Malnutrition. Cereal Science Today, 10, 458-461.

Shurtleff, W., \& Aoyagi, A. (2007). A Special Report on the History of Soybeans and Soyfoods in Africa and Around the World. A Chapter from the Unpublished Manuscript, History of Soybeans and Soyfoods: 1100 B.C. to the 1980s, Soyinfo Center, Lafayette, California. Available at http://www.iita.org. Retrieved on 4th December, 2010.

Smith, K., \& Huyser, W. (1987). World Distribution and Significance of Soybean. In Wilcox, J. R. (Ed.) Soybean: Improvement, Production and Uses. Third Ed. Agron. Monograph. 16. ASA, CSSA, and SSSA, Madison. Pp. 1-22.

Ugwu, D. S. (2009). Problems and Prospects of Commercial Small and Medium ScaleCocoa and Oil Palm Production in Cross River State, Nigeria. Journal of Applied Sciences Research, 5(7), 827-832.

Uwaegbute, A. C. (1992). Soyabean Miracle Protein: The Book of Soyabean. Japan Publications Inc. Tokyo and New York. 